Paedagogia Christiana

I/27 (20I I) - ISSN 1505-6872

Krzysztof Skorulski*

Innsbruck

\title{
Ferdinand Ebner i miejsce filozofii dialogu w myśli katolickiej XX wieku
}

Mówienie o filozofii dialogu w kontekście myśli katolickiej wydaje się, przynajmniej w Polsce, dość niecodzienne. Czyżby więc w Kościele katolickim nie myślano dialogicznie? Chcielibyśmy tu pokazać, że jest dokładnie odwrotnie: filozofia dialogu nie tylko ma w osobie stanowczo zbyt mało znanego Ferdinanda Ebnera swego katolickiego protoplastę, ale znalazła dostęp do samego serca filozofii i teologii XX wieku.

Warto wskazać na ten stan rzeczy, nawet jeśli usiłowanie opisania „katolickiej filozofii dialogu" jako nurtu całkowicie odrębnego względem myśli protestanckiej i żydowskiej skazane byłoby na niepowodzenie. Już od początku myślenie dialogiczne jest bowiem zjawiskiem ponadkonfesyjnym. Jeśli odwołujemy się do Ebnera, to stwierdźmy, że co prawda formułuje i wydaje swe myśli jako pierwszy, ale w następnych latach czyta ukazujące się - napisane po lekturze jego dzieła lub też po prostu z nim zbieżne - prace innych: Gwiazde zbawienia Rosenzweiga, Ja i Ty Bubera, Istote i formy sympatii Schelera, Ich glaube an den Dreieinigen Gott Gogartena oraz koresponduje z Hansem Ehrenbergiem. Integralną częścią tej ponadkonfesyjności są jednak od „Ebnerowskiego początku” impulsy katolickie, czy szerzej chrześcijańskie: przede wszystkim „uświadomione dopiero przez

* Dr Krzysztof Skorulski, kierownik Sekcji Badań Naukowych w Internationale-Ferdinand-Ebner-Gesellschaft w Innsbrucku, thumacz dzieł Bergsona, Ebnera i Rouvilloisa (H. Bergson, Dwa źródła moralności i religii, Kraków 1993; tenże, Energia duchowa, Warszawa 2004; F. Ebner, Stowo i realności duchowe. Fragmenty pneumatologiczne, Warszawa 2006; S. Rouvillois, New Age. Kultura i filozofia, Kraków 1996). 
ducha chrześcijańskiego"1 rozumienie Ja i zainspirowana pismami Janowymi koncepcja Słowa.

\section{Filozofia dialogu a zasada dialogiczna}

Na początku trzeba przyznać, że w użytku potocznym termin „filozofia dialogu" nie jest do końca jasny. Czy chodzi o pewną grupę filozofów z pierwszej połowy XX wieku, którzy wiązani są z terminem „filozofia dialogu", czasami nawet bez względu na to, co piszą? W kontekście tym, może poza takimi myślicielami jak Buber, Rosenzweig, Levinas, czasami Ebner (chociaż nawet odnośnie ich przynależności do tego kierunku zgłaszane są wątpliwości), wymieniane są jednak rozmaite nazwiska ${ }^{2}$. A może chodzi o refleksję filozoficzną nad zjawiskiem międzyludzkiego dialogu (lub szerzej „spotkania” czy „komunikacji”), którym w ramach nauk szczegółowych zajmuje się teoria komunikacji ${ }^{3}$, cybernetyka, psychologia, lingwistyka czy literaturoznawstwo? Jednak dialog w sensie komunikacji można widzieć na różne sposoby, niekoniecznie tak, jak czynią to nasi myśliciele, i kto wie, czy nie dlatego następuje obecnie pewnego rodzaju dewaluacja i deprecjacja terminu „dialog”. Podsumowując więc dotychczasowe próby zdefiniowania filozofii dialogu ${ }^{4}$, proponuję przyjąć tu jej następujący wyróżnik: skoro filozofia, a dokładniej pewne nastawienia filozoficzne niezbędne są do uprawiania także nauk szczegółowych, to za filozofię dialogu przyjmijmy takie myślenie, które ma za filozoficzną podstawę zasadę dialogiczną, tak jak ją ujmuje na przykład sam Ebner na początku swego podstawowego dzieła Stowo i realności duchowe, nazywając ją ,myślą podstawową":

Zakładając, że egzystencja ludzka w swoim jądrze ma w ogóle znaczenie duchowe, $[\ldots]$ wówczas to, co duchowe jest w sposób istotny określone przez to, że od samych podstaw nastawiony jest on (człowiek) na relację do czegoś duchowego poza nim, przez co i w czym on sam istnieje. Owo „bycie nastawio-

${ }^{1}$ F. Ebner, Stowo i realności duchowe. Fragmenty pneumatologiczne, Warszawa 2006, s. 9 .

2 Por. T. Gadacz, Historia filozofii XX wieku. Nurty, t. 2, Kraków 2009, s. 503-506. Gadacz zalicza do nurtu katolickiego np. M. Nédoncelle, J. Tischnera, J.-L. Marion. Zaś Urs von Balthasar wymienia jako dialogików nawet T. Adorno i W. Benjamina. Por. tenże, Theologik, Bd. 2: Wahrheit Gottes, Einsiedeln 1985, s. 42.

${ }^{3}$ Por. P. Watzlawick i in., Menschliche Kommunikation, Bern 1985.

${ }^{4}$ Por. T. Gadacz, dz. cyt.; K. Wuchterl, Bausteine zu einer Geschichte der Philosophie des 20. Jahrhunderts. Von Husserl zu Heidegger. Eine Auswahl, Bern 1995, s. 364nn. 
nym” na tego rodzaju relację wyraża się - i to właśnie w sposób „obiektywnie” ujmowalny i przez to dostępny obiektywnemu poznaniu - w fakcie, że człowiek jest istotą mówiąca, że „ma słowo”. [...] Jeśli więc, aby znaleźć słowo na określenie tej sytuacji, to, co duchowe w człowieku, nazwiemy Ja, zaś to, co duchowe poza człowiekiem, w relacji do którego Ja istnieje - Ty, musimy uwzględnić, że owo Ja i owo Ty dane są nam w swej „wewnętrzności” (Innerlichkeit) przez słowo i w nim; jednakże nie jako ,puste” wyrazy, które cechuje brak odniesienia do realności (chociaż tak właśnie jawią się one oczywiście w ich użyciu abstrakcyjnym, urzeczownikowionym i zsubstancjalizowanym), lecz raczej jako słowo, które w konkretności i aktualności swego bycia wypowiadanym, w sytuacji wytworzonej przez mówienie, „reduplikuje” swoją treść i zawartą w nim realność 5 .

Sens wypowiedzi Ebnera jest po pierwsze niewątpliwie taki, że ,realnie” „nie ma Ja bez Ty” - wszelkie rodzaje samotnego „Ja absolutnego”, typowe choćby dla niemieckiego idealizmu, są jedynie konstruktami intelektualnymi, ,pustymi wyrazami”. Co więcej, owe Ja i Ty - jako realności duchowe, a nie fikcje - dane są nam, i to ,obiektywnie” przez słowo i w słowie, ale w słowie ujętym „,w konkretności i aktualności swego bycia wypowiadanym" - a więc, inaczej mówiąc, w mowie, w konkretnej sytuacji mowy. Taka wizja człowieka jako „realności ducha” nie może jednak pozostać czystą zasadą myślenia, Ebner widzi ją znacznie szerzej. Jak pisze on sam: „W «odkryciu Ja i Ty» odkryta została jednak nie zasada myślenia, lecz zasada życia, zasada ludzkiego życia w jego «chcianej przez Boga» postaci"6. Ebner wychodzi bowiem z założenia, że wiążący się z tym ,przełom” w widzeniu człowieka nie może pozostać bez wpływu na konkretną egzystencję ludzką. Taka właśnie filozofia stanowiłaby pewnego rodzaju rewolucję w stosunku do nowożytnego myślenia ,idealistycznego”, byłaby owym „,nowym myśleniem" w sensie Rosenzweiga ${ }^{7}$. Dziedzina refleksji staje się wtedy obojętna, zaczyna chodzić raczej o pewien styl jej uprawiania. W ten sposób dany autor niekoniecznie musi być ,wyłącznie” filozofem dialogu (tzn. należeć do pewnej grupy), ale w naszym sensie jest nim „również”, jeśli stosuje w swym myśleniu, w interpretowaniu jego rezultatów zasadę dialogiczną. Dlatego też chętniej niż o „filozofii dialogu” mówimy tu o „myśleniu dialogicznym”.

Jeśli przyjmiemy powyższe określenie filozofii dialogu, to musimy przyznać, że nie jest możliwe przedstawienie w niniejszym szkicu nawet

${ }^{5}$ F. Ebner, Stowo i realności, s. 6 n.

${ }^{6}$ Por. tenże, Zum Problem der Sprache und des Wortes, w: tenże, Schriften, München 1963, Bd. I, s. 646.

${ }^{7}$ Por. F. Rosenzweig, Gwiazda zbawienia, Kraków 1998, s. 660nn. 
tylko najważniejszych „dialogicznych” myślicieli katolickich. Chcielibyśmy więc zwrócić uwagę przede wszystkim na „odkrywcę” zasady dialogicznej wraz z jej konsekwencjami: Ferdinanda Ebnera ${ }^{8}$ - katolika, chociaż krytycznego wobec ówczesnej doktryny i praktyki Kościoła - i wskazać na obecność zasady dialogicznej w myśleniu przynajmniej kilku znaczących postaci Kościoła katolickiego XX wieku.

Zaznaczmy przy tym z naciskiem, że w niniejszych rozważaniach nie chodzi o wykazywanie „wpływu” Ebnera na innych myślicieli, (poprzestańmy tu jedynie na stwierdzeniu jego czasowej precedencji ${ }^{9}$ ) ani też ich wzajemnych zależności. Naszym celem jest jedynie wskazanie na obecność zasady dialogicznej w myśleniu danego autora jako myśli przewodniej lub jako punktu odniesienia, nawet gdy obszary jego rozważań są rozległe, obejmujące nie tylko filozofię, lecz także tak różne dziedziny jak teologia, politologia, ekonomia, a nawet biologia komórek, fizyka czasstek czy literaturoznawstwo $^{10}$. Zasadę dialogiczną można by przy tym określić jako odkrycie tego rodzaju, że po jej przyswojeniu uważa się ją za część swego myślenia, trochę podobnie jak stosując się do zasad logiki nikt nie powołuje się przy tym otwarcie na Arystotelesa.

\section{Myśl dialogiczna przed Ebnerem}

Jak wiemy, cała fala myślenia „dialogicznego" zaczyna się w pierwszych dziesięcioleciach XX wieku, niejako w odpowiedzi na „,niedialogiczne" wydarzenie I wojny światowej. Ebner wpisuje się więc w pewien przewrót, dokonujący się w myśleniu jego czasów (będąc zarazem jego współautorem), wyrażający się w odrzuceniu myślenia idealistycznego, opartego na pewnej stałości i uniwersalności struktur, które w czasach Ebnera zaczynają

${ }^{8}$ Ebner był niewątpliwie tym, który wyciagnął z tej zasady ostateczne konsekwencje, samo jej sformułowanie ,unosiło się w powietrzu” już wcześniej. Gadacz przypisuje je Jacobiemu. Por. T. Gadacz, dz. cyt., s. 503. Podobne sformułowania - jak zobaczymy później znajdujemy jednak już u Hamanna czy Humboldta.

9 Według B. Caspera daje się wykazać nie tylko to, że Fragmenty, jego pierwsze „dialogiczne" dzieło, ukazały się najwcześniej, to znaczy najpierw jego części jako artykuły w czasopiśmie „Brenner”, a potem całość w postaci książki, lecz także na podstawie pamiętników, że dialogiczne sformułowania znajdujemy u Ebnera wcześniej niż na przykład u Rosenzweiga. Por. B. Casper, Das dialogische Denken: Franz Rosenzweig, Ferdinand Ebner und Martin Buber, Freiburg 1967, s. 198n.; K. Wuchterl, dz. cyt, s. 364n.

${ }^{10}$ Por. tematy wykładów organizowanych przez Międzynarodowe Towarzystwo Ebnerowskie, http://www.ebner-gesellschaft.org. 
się chwiać i padać ${ }^{11}$. Tym, co wydaje się pewniejsze niż struktury polityczne, społeczne czy kulturowe, zaczyna być sam człowiek. Zapewne więc nie przez przypadek pewien typ myślenia wzbudza, równolegle do przemyśleń Ebnera, zainteresowanie Maxa Schelera, a przede wszystkim grupy Rosenstock-Huessy, Cohen, Rosenzweig, Ehrenberg. Wkrótce potem okazuje się, że podobne zainteresowania kierują takimi myślicielami jak choćby Gogarten, Buber, Marcel, Guardini.

Chcielibyśmy jednak najpierw zastanowić się nad tym, czy w myśleniu filozoficznym już przed Ebnerem obecne są dialogiczne wątki, czy już wcześniej myślano na sposób dialogiczny. Jeśli bowiem zasada dialogiczna stanowi rzeczywiście podstawową zasadę widzenia i funkcjonowania człowieka, to dlaczego myślenie takie przez całe stulecia nie mogło przebić się w filozofii?

Powiedzmy na początku, że jeśli z naszą dzisiejszą wiedzą na ten temat będziemy poszukiwać śladów dialogiczności w myśleniu dawnych filozofów, to znajdziemy je szybko. Wspomnijmy tylko największych klasyków. Pierwszym, który musi się kojarzyć z dialogicznością jest Platon i jego dialogi (według Ebnera - pseudodialogi, gdyż w służbie maieutyki). Niewątpliwe ślady interesującego nas myślenia widzimy także u Augustyna: nie tylko dialogiczny styl jego Wyznańn ${ }^{12}$, ale i myślenie jako nieustanny dialog z ,wewnętrznym nauczycielem”: „W wewnętrznym człowieku mieszka Chrystus, jego pytamy, a on nas poucza". Dostęp do prawdy (dzisiaj powiedzielibyśmy: do rzeczywistości drugiej osoby, tu konkretnie osoby Chrystusa) zależny jest od zaufania, wiary i dobrej woli, otwiera się on ,pprzed duszą tylko na tyle, na ile jest ona w stanie to ująć, ze względu na swą złą lub dobrą wolę"13. Interesującym zajęciem byłoby doszukiwanie się śladów dialogiczności u Tomasza z Akwinu, przejawiającej się, moim zdaniem, chociażby w jego teorii aniołów (skoro Bóg jest, według Tomasza, „ponad Wszechświatem”, to $\mathrm{w}$ celu komunikacji z nim każdy człowiek dialoguje z posłanym do niego aniołem ${ }^{14}$, aczkolwiek chodzi tu o specyficzny dialog wewnętrzny) oraz

${ }^{11}$ Por. K. Skorulski, Znikajacy sens stów a narodziny filozofii dialogu. „Słowo” w koncepcji filozoficznej Ferdynanda Ebnera, „Logos i Ethos” 1/28 (2010), s. 15n.

${ }^{12} \mathrm{H}$. Urs von Balthasar widzi w Augustynie myśliciela „który trzymając się bez odstępstwa podstawowej myśli Ebnera formułuje swe podstawowe dzieło, Wyznania, jako wypowiedź swego Ja do Boga w formie modlitwy". Por. H. Urs von Balthasar, Theologik, Bd. 2: Wahrheit Gottes, s. 55.

${ }^{13}$ Por. Aurelius Augustinus, De magistro, 38 w: Der Lehrer. De magistro, Paderborn 1974, s. 84 n.

${ }_{14}$ Por. Summa theologica I, 61, 3 ad 2. „Bóg nie jest częścią wszechświata, lecz jest ponad całym wszechświatem [...] Anioł zaś jest częścią wszechświata”. Por. Summa theologica, t. 1, Paris, 1872, s. 1111. 
w teorii sakramentów. Wyraźniejsze sformułowania odnośnie do dialogiczności znajdujemy u takich autorów, jak von Humboldt, Jean Paul, Schelling, Franz von Baader, o których Ebner pisze, że w ich duchowym otoczeniu unosiło się już „odkrycie Ja i Ty"15. Humboldt pisze na przykład w swych rozważaniach nad istotą mowy: „W pierwotnej istocie mowy zawarty jest niewymienny dualizm, a sama możliwość mówienia uwarunkowana jest przez zagadnięcie i odpowiedź. [...] Człowiek tęskni, abstrahując od wszelkich relacji cielesnych i uczuciowych, także z konieczności samego swego myślenia, do Ty, odpowiadającego jego Ja" ${ }^{16}$. Baader zaś, w jednym z listów, pisze następująco o relacji Ja do Ty:

W pokorze i duchu mamy czy też zdobywamy tylko to, co dajemy, i dlatego dawca winny jest biorcy tyle samo wdzięczności, ile biorca dawcy, tzn. obaj dziękują Bogu, który w dawcy i w biorcy jest ten sam. W tym błogosławionym odkryciu, że ten sam w nas bierze i daje, który w nas szuka i znajduje, który w nas, przez nas i z nami spełnia i prosi, który jest światłem i okiem; w tym błogosławionym odkryciu, jak mówię, abstrakcyjne, ubogie Ja i Ty lub Nie-Ja przechodzi w bogate i wystarczające sobie My... ${ }^{17}$

Także Ludwig Feuerbach, znany ogólnie raczej ze swej krytyki chrześcijaństwa, był już bardzo blisko sformułowania zasady dialogicznej. Ebner, który o koncepcji Feuerbacha dowiedział się w latach dwudziestych od Hansa Ehrenberga, pisze o nim: „Feuerbach odkrył więc relację Ja do Ty, istotne powiązanie samoświadomości ze świadomością pewnego Ty; jednakże nie dane mu jeszcze było widzenie «obiektywnego» nośnika tejże relacji w słowie"18. Wymieńmy w tym kontekście jeszcze Kierkegaarda, któremu Ebner przypisuje szczególną zdolność czynienia z czytelnika jego pism „konkretnego" Ty ${ }^{19}$. Co ciekawe, ani Hamann, ani Humboldt czy też Feuerbach nie znajdująjednak wśród swoich współczesnych szczególnego odzewu. Teolog Hans Urs von Balthasar pisze odnośnie Hamanna, że „trzeba było jeszcze półtora wieku, aby Ebner odkrył jego teologię słowa"20".

${ }^{15}$ Ebner pisze w liście do Josefa Räuschera 16.01.1926: „Übrigens lag die «Entdeckung des Ich und Du» schon in der geistigen Luft um Humboldt, Jean Paul, Schelling, Baader herum". Por. F. Ebner, Schriften, B, III, s. 585.

${ }^{16}$ Por. W. von Humboldt, Ueber den Dualis, in: Schriften zur Sprachphilosophie, Werke, Bd. III, Berlin 1843, s. 137.

${ }_{17}$ Por. F. Werle (red.), Franz Baader und sein Kreis, Ein Briefwechsel, Leipzig 1924, S. 185.

18 Por. F. Ebner, Zum Problem, s. 647.

19 Por. tenże, Stowo i realności, s. 35n.

${ }^{20}$ H. Urs von Balthasar, Herrlichkeit, Vol I: Schau der Gestalt, Einsiedeln 1961, s. 78. 
Wydaje się, że przed wiekiem XX filozofia generalnie nie czyniła jeszcze dialogu swoim tematem, próbowała bowiem ciaggle rozwiązywać wielkie problemy w sytuacji samotnego myślącego podmiotu (kartezjańskie „myślę, więc jestem"). W podejściu filozofów zauważamy wyraźną różnicę między tym, czym zajmuje się „poważna” filozofia, a tym, o czym można - jak wyżej cytowany Baader - pisać w liście do młodej kobiety. Wydaje mi się także, że dialog konkretnych osób zastępowano dialektyką idei. Do przeoczenia problematyki Ja i Ty przyczyniło się niewątpliwie także to, że aby myśleć zgodnie z zasadą dialogiczną, trzeba mieć właściwą koncepcję Ja, czy też koncepcję osoby, nie wystarczy do tego koncepcja (wyabstrahowanego) podmiotu. Nieprzypadkowo Ebner krytykuje taką filozofię i wieszczy jej koniec ${ }^{21}$.

\section{Ferdinand Ebner i jego koncepcja slowa}

W myśleniu Ebnera centralne miejsce zajmuje niewątpliwie koncepcja słowa. To w niej sam Ebner widzi decydujący krok ku sformułowaniu zasady dialogicznej. Przy okazji prezentacji tejże zasady wspomnieliśmy już, że Ja i Ty dane są obiektywnie przez słowo i w słowie. Zrozumienie koncepcji słowa pozwala więc zrozumieć człowieka w ogóle, także w jego relacji z Bogiem. W naszych rozważaniach skoncentrujemy się więc przede wszystkim na ebnerowskiej idei słowa, widząc w niej istotny wkład filozofa z Gablitz w zrozumienie dialogiki.

\subsection{Słowo „właściwe” a słowo „techniczne”, dialogiczność a monologiczność}

Przede wszystkim Ebner rozróżnia między słowami w sensie technicznym (niem. Wort o liczbie mnogiej Woerter), a słowem „właściwym” (niem. Wort o liczbie mnogiej Worte). Te pierwsze to jednostki analizowane przez lingwistykę, znaki wchodzące w skład systemu znaków, za jaki uważany jest język. Tego rodzaju słowa można utożsamić z pojęciami. Ebner mówi o nich jako o słowach martwych. Jednak nie takie słowo interesuje filozofa z Gablitz. Chodzi mu przede wszystkim o słowo w drugim znaczeniu, o słowo ,żywe i sensowne”: słowo to jest słowem mówionym, „wydarza się” w codziennym życiu, ma moc działania. Jeśli „kieruję do kogoś słowo”, to znaczy, że nawiązuję z nim pewną relację. Słowo w tym znaczeniu jest więc

${ }^{21}$ Por. F. Ebner, Stowo i realności, s. 10. 
zdaniem, mowa, a pierwotnym zdaniem jest według Ebnera wyrażenie „Ja jestem". Tylko takie dialogiczne słowo ma ,znaczenie duchowe"22, jako że „stwarza ono zarówno bycie, jak i sens Ja i Ty. W słowie Ja i Ty są obiektywnie postrzegalne"23.

Jak wyjaśniłem gdzie indziej ${ }^{24}$, pasją Ebnera było przezwyciężenie myślenia monologicznego, związanego z ,ideą”, które nazywał ,idealizmem”, i przeciwstawianie mu myślenia dialogicznego, związanego nierozerwalnie ze „słowem”. Idealizm, jako „myślenie monologiczne”, zakłada „samowystarczalność jednej świadomości we wszystkich sferach życia". Idealiście wystarcza jedna (dokładnie mówiąc: własna) świadomość, podczas gdy myślenie dialogiczne potrzebuje więcej niż jednej świadomości ${ }^{25}$. I tu jest miejsce dla słowa właściwego.

\subsection{Słowo a osoba}

Według Ebnera, cechą wyróżniającą człowieka jest to, że człowiek „,ma słowo"26. Oznacza to, że może on „zagadnąć" Ty, oraz być zagadniętym przez Ty, czyli może stać się Ty dla innego Ja. W ten sposób stwierdzenie ,człowiek ma słowo” równoznaczne jest z: ,jest nastawiony na to, co duchowe poza nim”"27. „Mieć słowo” równoznaczne jest z „byciem osobą”. Ebner, rozważając różnicę między wypowiedzią egzystencjalną w pierwszej i drugiej, a wypowiedzią w trzeciej osobie, formułuje to następująco: „Ta nieusuwalna myślowo identyczność podmiotu wypowiedzi i jego predykatu [w wypowiedzi ,ja jestem” - K.S.] tworzy istotę twierdzenia egzystencjalnego w pierwszej i drugiej osobie, tam gdzie stwierdzane jest właśnie bycie w sensie osobowości, które jako takie zawiera w sobie odniesienie do wypowiedzi, do słowa, ponieważ osobowość i «posiadanie słowa» są jednym" 28 . Można więc wnosić, że być osobą to móc powiedzieć „Ja jestem” - lub „Ty jesteś" - i to tak, że wypowiedź ta (w obecności Ty) jest sensowna i skutkuje nawiązaniem relacji.

\footnotetext{
22 Por. tenże, Zum Problem, s. 646.

${ }^{23}$ Por. tamże.

${ }^{24}$ Por. K. Skorulski, dz. cyt., s. 20n.

${ }_{25}$ Por. Т. Федяева, Диалог и сатира, Sankt Petersburg 2004, s. 6, 32.

26 Por. F. Ebner, Słowo i realności, s. 6n, 12n. i inne.

27 Por. tamże, s. 6.

28 Tamże, s. 162.
} 


\subsection{Słowo w aktualności swego bycia wypowiadanym}

Wypowiedź „Ja jestem” pokazuje swój właściwy sens, jest „słowem właściwym" dopiero wtedy, gdy słowo to rozumiane jest w aktualności swego bycia wypowiadanym. Dopiero wtedy widać w pełni różnicę między słowem a pojęciem.

Aktualność słowa (np. „Ja jestem”) wypowiadanego między osobami zapewniona jest wtedy, gdy obie osoby są obecne, ich słowa są prawdziwe i mówione na poważnie oraz pozostają w pełnej zgodności. Można też mówić o ich wzajemnym zaufaniu czy też o wierze w słowo. Poprzez wiarę w słowo obie osoby zostają zmobilizowane do pewnego rodzaju interakcji, do wspólnego działania. Funkcją słowa jest więc łączenie osób, budowanie relacji Ja do Ty. Jeśli w takiej sytuacji ,,aktualnie” wypowiadam do drugiego słowo, to nie myśli on o „znakach językowych”, lecz wierzy temu słowu i stosownie do niego działa. Bez tej ,aktualności” słowo można pokawałkować i analizować pod względem gramatycznym ${ }^{29}$ - ale nie czyni się tego przed drugim człowiekiem.

\subsection{Słowo a milość}

Wspomnieliśmy, że z aktualnością słowa wiąże się zaufanie. Ebner formułuje to radykalniej i mówi o miłości. Słowo nie jest dla niego słowem prawdziwym bez miłości:

Tak więc słowo i miłość są ze sobą związane. Człowiek czerpie co prawda ze słowa i z umieszczonego w nim przez nie rozumu wszelką siłę poznania, jednak u podstaw swego „bycia-mu-danym” słowo służy miłości, miłości boskiej i wymaganej przez Boga miłości bliźniego. Właściwe słowo jest zawsze słowem wypowiedzianym przez miłość, ono zaś ma w sobie moc, by przełamać chińskie mury. [...] Słowo pozbawione miłości jest już jednak nadużyciem boskiego daru słowa. W nim słowo zwalcza swój własny sens i usuwa duchowo samo siebie ${ }^{30}$.

${ }^{29}$ Zwróćmy uwagę, że do takiego właśnie „słowa bez aktualności” jako do texte odnoszą się także analizy dekonstruktywizmu dotyczące intertekstualności. Por. R. Brütting, «écriture» und "texte». Die französische Literaturtheorie «nach dem Strukturalismus». Kritik traditioneller Positionen und Neuansätze. Bonn 1976, 73n.

${ }^{30}$ F. Ebner, Stowo i realności, s. 107. 
Realności życia duchowego, to znaczy Ja i Ty, mają dla Ebnera swoje bycie obiektywne w słowie, a subiektywne - w miłości. Ebner przedstawia to następująco: „Byciu danym obiektywnie w słowie tego ostatniego (Ty) odpowiada jego subiektywne istnienie w miłości, tak że słowo i miłość łączą się ze sobą w ich duchowej podstawie"31. Nie wystarczy zatem ,jakieś" słowo do wypełnienia misji łączenia Ja z Ty: chodzi o słowo „aktualne” i połączone z miłością, o „słowo właściwe”.

Miłość rozumiemy tu bardzo szeroko jako otwarcie na drugiego, jako pozytywny stosunek do niego. Bez miłości słowo nie wiąże mnie z Innym jako Ty, a nawet może zabić. Warto zauważyć, że Ebner - podobnie jak wielu myślicieli przed nim ${ }^{32}$ - przyjmuje, że otwartość człowieka - a więc owa „miłość" - jest pewną postawą która obejmuje jednocześnie zarówno jego stosunek do siebie, jak i do innego człowieka, a także do Boga i prawdopodobnie również do świata. Krótko mówiąc, nie da się kochać drugiego człowieka nie kochając siebie, a nawet nie kochając Boga... To pozytywne nastawienie do drugiego człowieka stwierdzalne jest tylko subiektywnie, niejako „od wewnątrz”, bo z zewnątrz mamy do niego dostęp jedynie w słowach i zachowaniach danej osoby.

\subsection{Słowo na początku}

Jak to się stało, że człowiek w ogóle „ma słowo”? To pytanie wiąże się dla Ebnera z pytaniem o genezę mowy i języka. Jego rozważania prowadzą go do innego aspektu słowa, do ,słowa na początku”. Pod wpływem inspiracji Prologiem Ewangelii wg św. Jana „słowo właściwe” okazuje się równoznaczne z biblijnym „Logos”.

Kto pierwszy wypowiada słowo? Kto czyni mnie osobą? Człowiek zauważa, że jest „zawsze już” zagadnięty, że zanim stanie się Ja, zawsze najpierw jest Ty jakiegoś Ja. Tym Ja, które „zagaduje” człowieka, jest więc dla Ebnera ostatecznie Bóg. Idąc po linii wywodu biblijnego, musimy też stwierdzić, że to Jezus Chrystus jest Słowem Boga do człowieka. Skoro słowo (z małej litery) jest tym, w czym (,obiektywnie”) dostrzegam Drugiego, to także Słowo (Jezus Chrystus) jest tym, w czym (a może raczej „w kim”) dostrzegam Boga. Jest to spojrzenie podobne do tego, które przepełnia malar-

31 Tamże, s. 20.

${ }^{32}$ Tego rodzaju wizję spotykamy w każdym razie u Tomasza z Akwinu, gdy jak np. w Summa Theologiae I, 117, 2 pisze on o (jednej) miłości, dotyczącej wszystkich tych obszarów, która jest ostatecznie zwróceniem ku Dobru. Cyt. za w: Thomas von Aquin, Das Auge des Adlers, ein Brevier der Heilslehre, red. J. Pieper, München, 1950, s. 132. 
stwo ikonowe: nie znajdujemy tam obrazów Boga Ojca, tylko Jezusa Chrystusa, ponieważ On sam powiedział „Kto mnie widzi, widzi także i Ojca”33. Ebnerowi - jak wspomnieliśmy - chodzi jednak nie tylko o myślenie, lecz o życie. Podkreśla więc, że w słowie - słowie Chrystusa zawartym w Ewangelii - dana jest człowiekowi „rzeczywistość Chrystusa”, której można doświadczyć, stosując choćby jakąś część tegoż słowa w swym życiü ${ }^{34}$.

\section{Filozofia dialogu w ramach myśli katolickiej XX wieku}

Spośród najważniejszych myślicieli katolickich, kierujących się w swym myśleniu ,zasadą dialogiczną,, wybierzemy tu jedynie takich, którzy znali i cenili pisma Ebnera, odnosząc się do niego otwarcie. Z oczywistych przyczyn nie będziemy w stanie $\mathrm{w}$ tym artykule ani zaprezentować całości ich koncepcji, ani nawet dokładnie skonkretyzować, w których punktach są wierni zasadzie dialogicznej, a w których nie. Chodzi nam raczej o pokazanie, że myśl dialogiczna w charakterystyczny dla niej „tajemny” sposób przenika także centralne nurty rozważań filozoficznych i teologicznych XX wieku.

\subsection{Romano Guardini}

Znaczenia takiej postaci jak Romano Guardini w dziele odnowy Kościoła katolickiego XX wieku nie trzeba szczególnie podkreślać. Chociaż wielorakość jego zainteresowań, mnogość pism i aktywności nie pozwalają nazwać go ,po prostu” lub ,tylko” filozofem dialogu, to także Romano Guardini uwzględnia w swym myśleniu o człowieku (i Bogu) zasadę dialogiczną.

Guardini wychodzi w swych rozważaniach antropologicznych od faktu zachwiania dotychczasowej pewności co do wiedzy o człowieku, zarówno tej humanistycznej - nauk humanistycznych, jak i technicznej - nauk ścisłych, co umożliwia postawienie na serio pytania o człowieka. Stara się on więc określić „chrześcijański obraz człowieka”, który przekracza dotychczasowe odpowiedzi na to pytanie, a który wyraża się w koncepcji „osoby”. W obrazie tym człowiekowi nie czyni się zadość, wskazując na jego wewnętrzność (Innerlichkeit), nawet jeśli ujmuje się ją jako samoświadomość,

${ }^{33}$ Nie możemy tu rozwijać tego ważnego w myśli Ebnera wątku. Dokładniejsze opracowanie tego tematu znajdziemy na przykład w: J. Jagiełł, Vom ethischen Idealismus zum kritischen Sprachdenken, München 1997, s. 230-298.

${ }^{34}$ Por. F. Ebner, Die Wirklichkeit Christi, „Der Brenner” 10 (1926), s. 44nn. 
źródło woli, źródło działania. O osobę możemy zapytać na dwa sposoby. Pierwszy: „Co to tutaj jest?” Odpowiedzią byłoby: ,istota ukształtowana, ugruntowana w wewnętrzności, określona duchowo i tworząca”. Gdy jednak zapytamy: „Kto to tutaj jest?” - odpowiedzią jest: „Ja”. Guardini pisze: „Dopiero teraz dotknęliśmy osoby" ${ }^{35}$. Osoba może być więc uwarunkowana jedynie przez drugą osobę (i od niej tylko zależna), nie przez żadne inne okoliczności zewnętrzne. Uwarunkowanie to określane jest jednak nie przez relację podmiot-przedmiot, co więcej: ,inny staje się moim Ty dopiero tam, gdzie kończy się prosta relacja podmiot-przedmiot" ${ }^{36}$. Guardini widzi więc człowieka jako osobę, która „istnieje w formie dialogu, nastawiona na inną osobę. Jest ona ze swej istoty przeznaczona do tego, by stać się Ja jakiegoś Ty. Nie ma osoby zasadniczo samotnej" ${ }^{\prime 37}$. Widzimy tu więc zastosowanie zasady dialogicznej. Nawet odnośnie do koncepcji mowy i słowa znajdujemy u Guardiniego analogie do Ebnera. Jako że człowiek „posiada dar mowy“ (Gabe der Rede), zaś mowa zakłada istnienie drugiego, mówienie popycha go do urzeczywistnienia relacji Ja-Ty. „W ten sposób mowa stanowi obiektywny szkic wstępny do dokonania się spotkania międzyosobowego"38. Także i „Bóg stworzył człowieka przez to, że go zawołał” ${ }^{9}$.

Oczywiste zbieżności między tymi myślami a sformułowaniami Ebnera skłoniły nawet samego Guardiniego, który z zasady nie zdradza swoich punktów odniesienia, do zajęcia w tej sprawie stanowiska. Pisze on: „Jak zwrócono mi uwagę, przedstawione tu myśli spokrewnione są z tym, które rozwijał Ferdinand Ebner" ${ }^{40}$. Pozostawiając tu na boku kwestię faktycznego wpływu Ebnera na Guardiniego, trzeba zwrócić uwagę, że Guardini jako jeden z pierwszych, jeszcze w latach dwudziestych, dostrzegł w myśleniu Ebnera potencjał, pomocny w odnowie myślenia w Kościele katolickim. Dlatego też nie tylko czytał prace Ebnera, ale i zaproponował mu współpra-

35 Por. R. Guardini, Welt und Person, Versuche zur christlichen Lehre von Menschen, Würzburg 1940, s. 94.

${ }^{36}$ Por. tamże, s. 106.

37 Por. tamże, s. 112.

${ }^{38}$ Por. tamże, s. 109.

39 Por. tamże, s. 114.

${ }^{40}$ Por. tamże, s. $114 \mathrm{n}$. Guardini podkreśla dalej własną samodzielność: „Czytałem z dzieł Ebnera tylko odosobnione fragmenty. Cieszę się więc ze zgodności, lecz mogę moje wywody pozostawić bez odwołania się do niego. Rzeczywiste impulsy zawdzięczam Theodorowi Haeckerowi, nie byłbym w stanie jednak podać, z jakiego pisma lub wypowiedzi." Dodajmy, że sam Theodor Haecker był entuzjastą i „popularyzatorem” Ebnera, a także tym, kto wprowadził go w krąg współpracowników czasopisma „Brenner”, przez co de facto umożliwił publikację Fragmentów. Z drugiej strony jego interpretacje Kierkegaarda pomogły Ebnerowi dokonać jego odkryć. 
cę w ramach redagowanego przez niego wówczas pisma „Schildgenossen”. Niestety, z powodu choroby Ebnera współpraca ta nie doszła ostatecznie do skutku.

Wychodząc od swego dialogicznego rozumienia osoby (jako jednej z podstaw jego „chrześcijańskiego światopoglądu”) może Guardini rozwijać swoje koncepcje na tak różnych obszarach, jak etyka polityczna (,zasada demokratyczna"41), objawienie (zagadnięcie człowieka przez Boga) czy liturgika (Chrystocentryzm - Jezus Chrystus jako Słowo Boga do człowieka). Co więcej, podejście takie, to znaczy wychodzenie od danych zjawisk, analizowanie ich i zajęcie względem nich stanowiska $\mathrm{z}$ punktu widzenia chrześcijańskiej wizji świata, widziane jest jako jego szczególnie mocny punkt ${ }^{42}$. I tak możemy widzieć w Guardinim klasyczny przykład jeśli nie „filozofa dialogu”, to wszechstronnego myśliciela stosującego się do zasady dialogicznej.

\subsection{Gabriel Marcel i personalizm}

Wpływ takiej postaci jak Gabriel Marcel na myślenie środowisk katolickich XX wieku trudno wręcz przecenić. Zestawiając Marcela z myślicielami niemieckimi, trzeba najpierw ogólnie zauważyć, że w obszarze języka francuskiego myślenie dialogiczne podążało drogą własną, chociaż analogiczną do myśli niemieckiej. Kierunki, w których praktykowano myślenie dialogiczne, nazywano „egzystencjalizmem chrześcijańskim” oraz personalizmem $^{43}$. Tak więc nic dziwnego, że wyrastając na francuskiej tradycji filozoficznej, Marcel oddaje zasadę dialogiczną, używając innych terminów.

${ }^{41}$ Zasada demokratyczna: „Dasein opiera się na wielości osób: na różnorodności ich poglądów, ich społecznych i kulturalnych impulsów. Wielość ta jest uprawniona i może udowodnić swoje prawo poprzez samodzielnie określony styl życia i wkład pracy; i tak jedność może dojść do skutku zawsze jedynie przez również wolne współdziałanie. ” Por. R. Guardini, Pluralität und Entscheidung, w: tenże, Sorge um den Menschen, Würzburg 1962, s. 137.

${ }^{42}$ Por. W. Dettloff, Romano Guardini (1885-1968), w: Klassiker der Theologie, B.2, Muenchen 1983, s. 323.

${ }^{43}$ Być może dlatego właśnie - po pojawieniu się Levinasa - termin „filozofia dialogu” zostaje przyporządkowany także w Polsce przede wszystkim grupie myślicieli żydowskich, tak że np. Gadacz czuje się zobowiązany podkreślić, że „filozofia dialogu nie była tylko filozofią żydowską, jak głoszą obiegowe opinie, lecz w równym stopniu chrześcijańską". Por. T. Gadacz, dz. cyt., s. 503. Z kolei Ebner (notabene: wraz z Buberem) zostaje nazwany ,dialogicznym personalistą". Por. J. Ratzinger, Dogmatische Konstitution über die Göttliche Offenbarung, Dei Verbum, Das Zweite Vatikanische Konzil: Dokumente und Kommentare, Teil II, Freiburg 1967, s. 506. 
Dlatego też, obok faktu, że jest on myślicielem niewątpliwie samodzielnym, wielowątkowym, a przez to trudnym do ,zaszufladkowania”, niekoniecznie wymieniany jest wśród dialogików. Marcel określany jest najczęściej - podobnie zresztą jak Ebner ${ }^{44}$ - jako „egzystencjalista chrześcijański” ${ }^{45}$, on sam zaś najchętniej określał się jako „chrześcijański sokratyk”.

Chociaż Marcel nie lubi być nazywany egzystencjalista, kieruje się w swoim myśleniu nie na ideę, lecz - jak sam mówi - „konkretnie na egzystencję, i to nie tylko na moją egzystencję, lecz także na Ty" ${ }^{\prime 4}$. Także i on odrzuca w spotkaniu międzyludzkim spojrzenie intencjonalne: „Inny jako taki, jako egzystujący, jest dla mnie nie przedmiotem, (oczywiście może stać się przedmiotem, takie niebezpieczeństwo istnieje)”. „To, co egzystencjalne”, nazywa Marcel „intersubiektywnością”, „my razem”. Gdy zaś stwierdzimy, że ,intersubiektywność jest dla Marcela istotą osoby”, lub inaczej mówiąc: „człowiek dąży do wspólnoty” ${ }^{47}$, to tym samym odkrywamy u podstaw jego myślenia zasadę dialogiczną.

Radykalna samotność, rozumiana jako zamknięcie na drugiego człowieka, równoznaczna jest z samobójstwem, w przenośni, a nawet dosłownie. Rozróżnianie między „Ja” a „moim życiem” - od którego musi wyjść zamiar pozbawienia „Ja” jego życia - dokonuje się bowiem w samotności. „Kto się wycofuje, kto żegna się z życiem, powinien zauważyć, że jego postawa zawiera w praktyce całkowitą samowystarczalność" ${ }^{48}$. Jeśli mówimy, że życie jest darem (czyli zakłada relację), to jesteśmy za nie odpowiedzialni. Jeśli widzę siebie jako monadę, to odpowiedzialność ta zanika.

Dostęp do istoty innego otwiera mi nie intencjonalność, lecz „dyspozycyjność” (disponibilité, „bycie do dyspozycji”), bezwarunkowe „zdanie się na coś [dokładniej: na „Ciebie”, K.S.], co nigdy nie będzie dla mnie obiek-

${ }^{44}$ Dla potwierdzenia wystarczy przyjrzeć się wynikom wyszukiwania hasła „Ferdinand Ebner" w internecie: por. Masakichi Kobayashi, Das Wort und die Liebe im christlichen Existentialismus Ferdinand Ebner, <http://www.sed.tohoku.ac.jp/library/nenpo/contents/15/1503.pdf>; Friedrich Heer, Der Philosoph aus dem Cafe Lehn, <http://www.noekulturforum. at/frames/texte/show_1_text.php?p_id=2\&buchstabe=alle\&suchwhat=autor $>$ lub niemiecki artykuł w Wikipedii o Ebnerze, $<$ http://de.wikipedia.org/wiki/Ferdinand_Ebner>.

${ }^{45}$ Sam Marcel nazywa „zdanie, że jestem eksponentem chrześcijańskiego egzystencjalizmu” "nieporozumieniem, za które odpowiedzialny jest w pierwszym rzędzie Sartre. To nie ma sensu". Por. G. Marcel, Mein philosophisches Testament, w: tenże, Werksauswahl, B. III: Unterwegssein, Paderborn 1992, s. 320.

46 Por. tamże, s. 324.

${ }^{47}$ Por. P. Grotzer, Einleitung, w: G. Marcel, Werkauswahl, B. III: Unterwegssein, s. 9.

${ }^{48}$ Por. G. Marcel, Mein Leib mein Sein mein Leben (Referat 1967 Freiburg i.B.), w: tenże, Dialog und Erfahrung, Frankfurt a. M. 1969, s. 122. 
tywne”. W ten sposób możemy przejść od „Mieć” do „Być”, charakteryzującego prawdziwie ludzkie odniesienia.

Także i Marcel rozważa, dokonując często analiz fenomenologicznych a jednocześnie trzymając się zasady dialogicznej, różne „obszary” człowieka. Ważne i często powracające w jego twórczości zarówno literackiej, jak i filozoficznej tematy to na przykład ciało i cielesnośćc ${ }^{9}$, nadzieja, wiara („wierzyć [...] znaczy zawsze wierzyć w jakieś Ty, to znaczy w jakąś realność osobową" ${ }^{50}$ ), wierność.

Gabriel Marcel jest więc myślicielem bliskim Ebnerowi, a także ceniącym i uznającym jego pierwszeństwo (obok Rosenzweiga) na polu filozofii dialogu ${ }^{51}$. Być może - jak sugeruje Zucal - inspiracja Ebnera jest w myśleniu Marcela nawet szersza, niż on sam to przyznaje, na przykład gdy przypomnimy sobie jego dążenie to tego, by poziom „posiadania” (w ramach dialektyki „być-mieć”) był transcendowany w miłości, dla której inny nie jest już przedmiotem (On), lecz doświadczanym w dialogu Ty ${ }^{52}$. Oczywiście także i Marcel, podkreślając własną oryginalność, wskazuje na różnice, które widzi bądź w radykalnym chrystocentryzmie Ebnera, który - jak sugeruje Marcel - wydaje się przeoczać Ty ludzkie, by w człowieku kierować się bezpośrednio do Chrystusa ${ }^{53}$, bądź w rozwijaniu przez Marcela - niewątpliwie nieakceptowalnej dla Ebnera - „filozofii My, w której Ja i Ty wydają się stanowić pewnego rodzaju jedność metafizyczną" ${ }^{4}$.

Jak już wspomnieliśmy, analogicznie do przeważnie niemieckojęzycznej filozofii dialogu mieliśmy do czynienia z rozwojem innego, pokrewnego (aczkolwiek wykazującego też różnice), przeważnie francuskojęzycznego kierunku filozoficznego: personalizmu. Przyjrzyjmy się „,samodefinicji” tego kierunku, jaką jest Manifest personalistyczny Mouniera. Odnośnie krytyki idealizmu czytamy w nim: „Nie ma żadnego nieosobowego ducha, nieoso-

${ }^{49}$ Nawet gdy pod koniec życia sam przyznaje, że „dzisiaj skłania się ku temu, by zastanawiać się bardziej nad swoim życiem, nie zaś nad cielesnością" (a więc analogicznie do Ebnera), w końcu mówiąc o ciele myślimy o nim jako o „ciele w jego żywej rzeczywistości, nie zaś o ciele martwym.” Por. tamże, s. 117.

${ }^{50}$ Por. tenże, Schöpferische Treue, w: tenże, Werkauswahl, B. III: Unterwegssein, s. 201.

${ }^{51}$ Por. tenże, Die geistige Entwicklung Ferdinand Ebners, w: tenże, Dialog und Erfahrung, s. $111 \mathrm{n}$.

${ }_{52}$ Por. S. Zucal, Ferdinand Ebner, la ,nostalgia“ della parola, Brescia 1999, s. 196.

${ }^{53}$ Por. G. Marcel, Die geistige Entwicklung, s. 111n. Należy jednak zaznaczyć, że owo podejrzenie o taki chrystocentryzm, sugerowany już przez Bubera, nie wydaje się uzasadnione, a jeśli już, to raczej na płaszczyźnie osobistej, na którą wskazuje Marcel, niż teoretycznej. Por. Zucal, dz. cyt., s. 197.

${ }^{54}$ Por. tamże, s. 197. 
bowego wydarzenia, nieosobowej wartości, nieosobowego losu"55. Przypomnijmy też, że dla personalistów osoba konstytuuje i realizuje się wyłącznie poprzez jej odniesienie do innej osoby. W tym kontekście to, co Ebner nazwałby „relacją Ja do Ty”, nazywa się „,wspólnotą” czy może lepiej „komunią osób” (la communion) i dialogiem. Mounier pisze: „Uważamy, że wspólnota («komunia») włączona jest w samo serce osoby, stanowiąc integralną część samej jej egzystencji" ${ }^{56}$. Na tej podstawie Mounier odróżnia personalizm od indywidualizmu. Nie jest tu naszym zadaniem analiza zbieżności i różnic obu kierunków, zauważmy jednak, że skoro - jak sugeruje choćby autor niemieckiej wersji Wikipedii - daje się wykazać wpływ Marcela na Mouniera ${ }^{57}$, można - pamiętając o wszelkich różnicach - rozciagnąć oddziaływanie myśli dialogicznej także na prąd myślowy personalizmu i takich inspirowanych personalizmem myślicieli jak Paul Ricoeur czy Karol Wojtyła.

\subsection{Teologia katolicka: Karl Rahner, Hans Urs von Balthasar i Sobór Watykański II}

Wśród teologów katolickich zainspirowanych myślą dialogiczną wymieniani są tak znaczący myśliciele jak Karl Rahner i Hans Urs von Balthasar. Przyjrzyjmy się najpierw pierwszemu z nich. Choć znany jest fakt, że Rahner czerpie w swej antropologii filozoficznej od Heideggera, to niewielu wie, że od Ebnera ma on swoją koncepcję „Słuchacza słowa" ${ }^{58}$. Według opinii znawcy Rahnera, A. Raffelta, ta niewielka książka, „ostatnie dzieło filozoficzne" Rahnera - także przez swój programowy tytuł - trwale wpłynęła na teologię, szczególnie tę drugiej połowy XX wieku ${ }^{59}$. Jeśli czytamy to dzieło znając Ebnera i interpretujemy je w jego sensie, to mimo heideggerowskiej i rahnerowskiej terminologii oraz zasad rozwijania myśli odkrywamy w zarysie zasadę dialogiczną, z tym że zastosowaną do relacji człowieka z Bogiem. Spójrzmy chociażby na określaną przez Rahnera podstawową konstytucję człowieka: należy oczywiście do niej „bycie-u-siebie”

${ }_{55}$ Por. E. Mounier, Das personalistische Manifest, Zürich, 1936, s. 81.

${ }^{56}$ Por. tamże, s. 96.

57 Por. T. Gadacz, dz. cyt., s. 449.

58 Por. K. Rahner, Stuchacz słowa. Ugruntowanie filozofii religii, Kraków 2008. Według ustnej relacji prof. Silvano Zucal, wówczas doktoranta w Innsbrucku, na jego pytanie, skąd wziął swoje sformułowanie o „słuchaczu słowa”, czy też od Heideggera? Rahner odpowiedział wyraźnie: „nie, mam je od Ebnera”. Relacja prof. Silvano Zucal, mieszkańca miasta Trento (Włochy) i profesora na tamtejszym uniwersytecie, uzyskana 17.03.2009.

59 Por. A. Raffelt, H. Verweyen, Karl Rahner, München 1997, s. 41. 
(bei-sich-Sein), ale poza tym: ,człowiek jest absolutną otwartością na wszelkie Bycie [tu: Bóg albo człowiek, K. S.], albo, by wyrazić to w jednym słowie, człowiek jest duchem”60. Tak więc „do fundamentalnej konstytucji człowieka należy aprioryczna, absolutna transcendencja na bycie jako takie, dlatego też człowiek nazywany jest duchem" ${ }^{61}$. Także i rola słowa w „komunikowaniu” bycia zostaje zauważona: „Bycie jest rozjaśnione, jest «Logosem» i w ten sposób może być wypowiedziane w słowie" ${ }^{2}$. Także i tu słowo łączy się z miłością: „Człowiek słucha mowy lub milczenia Boga w tym zakresie, w jakim otwiera się w wolnej miłości na ten przekaz mowy lub milczenia Objawienia"63. Również Rahner podkreśla konkretność człowieka, w tym przypadku poprzez akcentowanie jego materialności i historyczności ${ }^{64}$. Nie mamy tu oczywiście zamiaru sugerować pełnej zgodności myślenia Rahnera i Ebnera. Swoje nastawienie trafnie charakteryzuje sam Rahner, recenzując cytowane przez nas „bardzo ebnerowskie” dzieło Guardiniego Welt und Person: „Z pewnymi punktami nie można się całkowicie utożsamić: wtedy, [...] gdy osoba i chrześcijańska osoba, podobnie jak u Ebnera i Brunnera, postawione zostają zbyt blisko siebie. Jednak zawsze czyta się z wdzięcznością te próby, które uczą nas podstawowych kategorii chrześcijańskiej nauki o człowieku w nowy i pierwotny sposób" ${ }^{65}$.

Bardzo ważną rolę w naszym kontekście odgrywa Hans Urs von Balthasar, który nie tylko często otwarcie odwołuje się do „dialogików”, w tym do Ebnera, lecz myśli na sposób dialogiczny. Urs von Balthasar jest oczywiście w swym myśleniu teologiem, ale w jego przekonaniu „dialogicy są filozofami, którzy do przeprowadzenia samej swej myśli potrzebują teologii" ${ }^{\prime 66}$. Według Zucala, cała dialektyka przenikająca balthasarowską teologię jest faktycznie odmieniana w kluczu dialogicznym ${ }^{67}$. Dialogiczność widoczna jest na przykład w Trójcy i znajduje swój obraz w człowieku, będącym imago trinitatis. Także i u Balthasara człowiek rozumiany jest zasadniczo jako osoba „zagadnięta”, fundamentalnie stojąca w relacji z Ty boskim i ludzkim. Dlatego też to właśnie dialogika pozwala człowiekowi najbardziej zbliżyć

${ }^{60}$ Por. K. Rahner, Hörer des Wortes. Zur Grundlegung einer Religionsphilosophie, München 1941, s. 68.

61 Por. tamże.

62 Por. tamże, s. 86.

63 Por. tamże, s. 136.

${ }^{64}$ Por. tamże, s. 141

65 Por. tenże, [Rezension], Guardini, R.: Welt und Person (1939), „Zeitschrift für katholische Theologie" 65 (1941), s. 50.

${ }^{66}$ Por. H. Urs von Balthasar, Theologik, Bd. 2: Wahrheit Gottes, s. 45.

67 Por. S. Zucal, dz. cyt. s. 206n. 
się do odpowiedzi na pytanie „kim jestem”68. Jednak przy całym szacunku dla dialogiki także Urs von Balthasar daleki jest od utożsamiania się z którymkolwiek z jej myślicieli. Na przykład myślenie Ebnera uważa za „strome" i „wąskie" 69 , i w swym opus magnum (Theodramatik/Theologik) stara się je przekroczyć.

Skoro tak znaczący myśliciele katoliccy posługiwali się zasadą dialogiczna, to nic dziwnego, że wpływ myślenia dialogicznego daje się zauważyć także w dokumentach Soboru Watykańskiego II. Widać to chociażby na przykładzie przemiany w rozumieniu boskiego Objawienia w stosunku do Vaticanum I. Szczególnie Konstytucja Dei Verbum, jak podkreśla to Josef Ratzinger, prezentuje nowe rozumienie boskiego Objawienia, które w ciągu ostatniego stulecia ukształtowane zostało znacząco przez dialogiczny personalizm Ferdinanda Ebnera, Martina Bubera i innych (w dużej mierze poprzez wpływ Karla Bartha) ${ }^{70}$. Wizja Objawienia Bożego zrywa tu z jego legalistycznym przedstawieniem jako dekretu Boskich decyzji i przeciwstawia mu rozumienie woli Bożej jako sacramentum: „wizja sakramentalna, która prawo i łaskę, słowo i czyn, Nowinę i znak, osobę i jej wyrażenia zawiera w ogarniającej to wszystko jedności Mysterium" "71. To Misterium zaś jest niczym innym jak sam Chrystus, jest osobą. Znajduje tu więc swe odzwierciedlenie dialogiczny obraz człowieka:

Boskie «zagadnięcie»: «Nie nazywam was sługami, lecz przyjaciółmi» wydarza się tu i teraz, oraz chce doprowadzić nas do odpowiedzi. I tak staje się widoczne, że myślenie o Objawieniu szkicuje zarazem pewien obraz człowieka: człowiek jako istota dialogiczna, która w słuchaniu Słowa Bożego staje się jednoczesna teraźniejszości Boga i we wspólnocie słowa otrzymuje (swa) rzeczywistość, nierozdzielną od tegoż słowa: wspólnotę z samym Bogiem ${ }^{72}$.

*

Pokazaliśmy tu, że filozofia dialogu, jeśli rozumiemy ją nie jako doktrynę określonej grupy myślicieli, lecz jako myślenie dialogiczne, czy dokładniej jako myślenie opierające się na zasadzie dialogicznej, wydało się

${ }^{68}$ Por. H. Urs von Balthasar, Theodramatik, Bd. 1: Prolegomena, Einsiedeln 1973, s. $587 \mathrm{nn}$.

${ }^{69}$ W oryginale: schmal und steil. Por. H. Urs von Balthasar, Theologik, Bd. 2: Wahrheit Gottes, s. 51.

${ }^{70}$ Por. J. Ratzinger, dz. cyt. s. 506.

${ }^{71}$ Por. tamże, s 506n.

${ }^{72}$ Por. tamże, s. 507. 
na tyle wartościowe, właśnie zarazem „nowe i pierwotne” (K. Rahner), że z biegiem czasu przeniknęło do serca rozważań filozoficzno-teologicznych prowadzonych w Kościele katolickim i jeśli nie dominuje, to stanowi co najmniej interesującą alternatywę wobec propozycji wypracowywanych przez współczesne kierunki filozoficzne. Co więcej, przyjmując wizję Urs von Balthasara, możemy stwierdzić pewną szczególną symbiozę pomiędzy myśleniem kierującym się zasadą dialogiczną a myśleniem teologicznym: dopiero dialogiczne widzenie człowieka umożliwia zbliżenie się do odpowiedzi na pytanie „kim jestem” (także wobec Boga), sama zaś dialogika „,czysto filozoficzna”, gruntowana na spotkaniu wyłącznie międzyludzkim wydaje się pozbawiona stabilnych podstaw ${ }^{73}$.

Prawdopodobnie taki rozwój wypadków nie byłby możliwy bez początkowego impulsu, wychodzącego z rozważań nad „Słowem” w Prologu Ewangelii według św. Jana, prowadzonych przez „odkrywcę” zasady dialogicznej: Ferdinanda Ebnera, owego „katolickiego mistrza” (jak określił go Rosenzweig ${ }^{74}$ ), który, chociaż krytyczny wobec wszelkiego - także kościelnego - monologizmu, wzywa dziś tak jak przed niemal stuleciem do zajęcia się rzeczywistym człowiekiem i jego egzystencją w świetle zasady dialogicznej, i to w sensie nie czystej refleksji, lecz by pozwolić mu żyć pełnią życia.

\section{Ferdinand Ebner und die Position der Dialogphilosophie innerhalb des katholischen Denkens im 20. Jh. (Zusammenfassung)}

Auch wenn es im ersten Moment etwas ungewöhnlich erscheinen mag, von einer katholischen Dialogphilosophie zu sprechen, ist das Ziel dieses Artikels zu zeigen, dass das dialogische Denken nicht nur einen katholischen (Mit-) Begründer - Ferdinand Ebner -, sondern auch einen festen, zentralen Platz innerhalb des katholischen Denkens hat. Als Kriterium, nach dem das dialogische Denken gesucht wird, wird hier weder die Zugehörigkeit zu einer Gruppe, noch das Thematisieren der Dialog/Kommunikation-Problematik angenommen, sondern das Denken nach dem dialogischen Prinzip. Dieses Prinzip wird hier anhand des „Grundgedankens” aus Ebners „Pneumatologischen Fragmenten” dargestellt und an seinem Konzept des Wortes weiter verdeutlicht. Doch bereits vor der „Dialogischen Wende“ lassen

${ }^{73}$ Por. H. Urs von Balthasar, Theodramatik, Bd. 1: Prolegomena, s. 590.

${ }^{74}$ Por. F. Rosenzweig, Der Mensch und sein Werk. Gesammelte Schriften I: Briefe und Tagebücher, Vol. II, Haag 1979, s. 889. 
sich Ansätze des dialogischen Denkens in der Philosophie entdecken. Als Beispiele werden hier unter den Klassikern Platon und Augustinus genannt und als nähere Wegbereiter des Ebner'schen Denkens Hamann, Baader, Humboldt und Feuerbach sowie Kierkegaard angesprochen. Als Illustration der Wirkung dieses Prinzips in dem katholischen Denken werden hier nur solche Denker erwähnt, bei denen wir einen direkten Bezug zu Ebner finden: Romano Guardini, Gabriel Marcel (mit seinem Einfluss auf Emmanuel Mounier), sowie die Theologen Karl Rahner und Hans Urs von Balthasar. Das Hauptanliegen ist dabei nicht die Frage nach dem Einfluss Ebners, sondern die nach der Gegenwart des dialogischen Prinzips in ihrem Denken. Weiterhin wird der Einfluss des dialogischen Prinzips in den Dokumenten des Vaticanum II anhand der Konstitution „Dei Verbum“ aufgezeigt. So lässt es sich nachweisen, dass zwischen dem dialogischen und dem „katholischen“ Denken in der Tat eine tiefe Symbiose besteht. 